\title{
DeEp diving With the USE Of a CRABE REBREATHER
}

\section{Ryszard Kłos}

Polish Naval Academy, Department of Underwater Work Technology in Gdynia, Poland

\section{ABSTRACT}

The article provides the results of 31 experimental dives carried out within the depth range of $H \in[60 ; 80] \mathrm{mH}_{2} \mathrm{O}$. A combined mathematical model for ventilation and decompression was proposed with the possibility of an emergency omission of the last station at $3 \mathrm{mH}_{2} \mathrm{O}$ and decompression completion at $6 \mathrm{mH}_{2} \mathrm{O}$ in the event of a deterioration in weather conditions

Keywords: diving apparatus, validation of decompression.

ARTICLE INFO

PolHypRes 2015 Vol. 51 Issue 2 pp. 11-30

ISSN: 1734-7009 elSSN: 2084-0535

DOI: $10.1515 /$ phr-2015-0008

Pages: 20, figures: 10 , tables: 3

page www of the periodical: www.phr.net.pl

Publisher

Polish Hyperbaric Medicine and Technology Society

\section{Original article}

Delivery date: $12.04 .2015 r$

Date of approval for print: $25.05 .2015 r$. 


\section{INTRODUCTION}

The starting point for undertaking the works in question was the purchase of a new piece of diving apparatus -the $C R A B E$ rebreather. This French produced rebreather is a successor to the FENZY - 68 apparatus. The article will not describe operation of the rebreather or the approach to modelling its ventilation, as these matters had been presented previously [10].

\section{Nature of the Problem}

The need to begin to utilise the $C R A B E$ rebreather was necessitated by a requirement to conduct proper training activities for divers. Initially it was planned to apply the decompression system used by the French Navy, however later it was decided to construct a national system.

In the years between 2009-2011 a decompression system for training dives was introduced within the implementation of project no. 0001/R/T00/2009108 entitled "Designing decompression in combat missions", commissioned by the National Centre for Research and Development.

Currently, activities are being undertaken to prepare technologies for the use of the said apparatus and decompression for underwater operations such as $\mathrm{MCM}^{1}$ and $E O D^{2}$ with the use of artificial breathing mixes for depth ranges reaching $\mathrm{H} \in[60 ; 80] \mathrm{mH}_{2} \mathrm{O}$ and $\mathrm{Tx}-$ $S C R$ CRABE SCUBA ${ }^{3}$ rebreather.

Preparation and adoption of the determined decompression calculation and validation procedures is crucial, as it constitutes the basis for defining the method of evaluating diving safety. The project allowed the determination of a method for anticipating the risk of decompression sickness and calculating the appropriate amount of decompression to be completed on sapper missions.

The determination of this method will enable enhancement of the operational potential in terms of utilisation of the $C R A B E^{4}$ rebreather in underwater countermine activities. The implementation of a developmental project entitled "Designing decompression for MCM dives" was approved by the
Bioethical Committee of the Military Medical University of Warsaw, allowing the continuation of experiments with the participation of humans within agreement no. DOBR/0047/R/ID1/2012/03. The publication contains results of the research carried out by the Naval Academy of Gdynia, later referred to as $A M W$, financed from the educational fund for the years 2013-2015 within the said project.

\section{METHOD}

\section{Decompression assumptions}

The article contains results of an analysis of 31 experimental trimix dives ${ }^{5} T x$ carried out by $A M W$ with the use of $T x-S C R$ CRABE SCUBA rebreather. In previous analyses 6 the adopted comparative values were the decompression distributions generated by $A B Y S S$ software for liberal method Abyss - 100. Distributions which were initially believed to be safe 7 were those obtained with the AMW approach taking into account the ventilation model of the breathing space of the rebreather 8 [9]. The proposal of a new decompression system was based solely on the AMW approach, in consideration of previous agreements with the project manager $[13,14]$.

It was assumed that the minimal oxygen content in the circuit during the time of a stay at the bottom $C_{O_{2}}^{\min }$ will be higher than $C_{O_{2}}^{\min } \geq 21 \%{ }_{v} O_{2} / T x$. This was carried out on the basis of former studies on nitrox mixtures ${ }^{9} \mathrm{Nx}$ [9].

It was assumed that $10 \mathrm{~min}$ before the descent a diver will breathe with $T x$ from the apparatus on the surface.

Oxygen decompression stations were applied starting at $12 \mathrm{mH}_{2} \mathrm{O}$, however the triple ventilation of the circuit with oxygen was conducted already at the station at $15 \mathrm{mH}_{2} \mathrm{O}$ prior to departure - fig. 1 . Triple ventilation of the breathing space with oxygen consists of a triple repetition of a single ventilation procedure involving triple exhalation of the breathing mix from the lungs into the

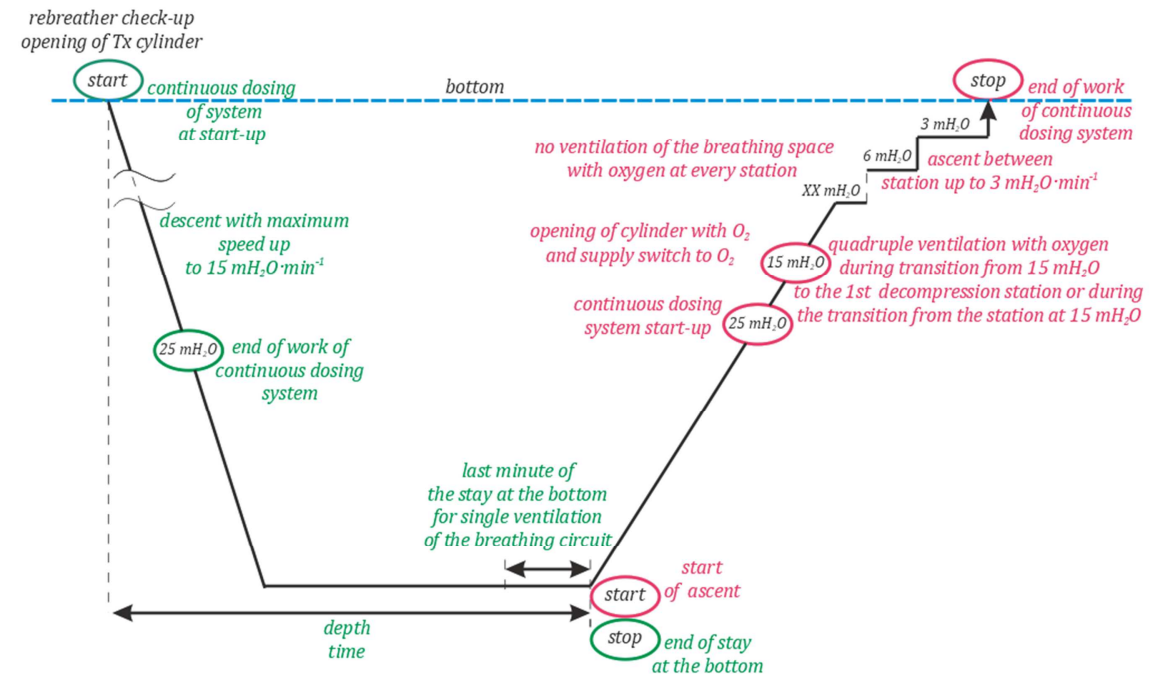

Fig. 1. Decompression profile $T x$ acc. to AMW approach 
water and filling the breathing space with oxygen. In the absence of the $15 \mathrm{mH}_{2} \mathrm{O}$ station, oxygen supply is activated at the depth of $15 \mathrm{mH}_{2} \mathrm{O}$, whereas the breathing space ventilation with oxygen occurs during the ascent to the first decompression station below the depth of $15 \mathrm{mH}_{2} \mathrm{O}$. The speed of reaching the first station was defined as $\dot{v}<15 \mathrm{mH}_{2} \mathrm{O} \cdot \mathrm{min}^{-1}$.
During oxygen decompression at the time of transition between the stations at $\dot{v}<3 \mathrm{mH}_{2} \mathrm{O} \cdot \mathrm{min}^{-1}$ it was recommended to conduct a single ventilation of the breathing space. Single ventilation entails triple exhalation of the breathing mix from the lungs into the water and filling of the breathing space with oxygen. The experiments revealed that such ventilation was not necessary, though nonetheless recommended. 
Example regular and emergency decompression table $T x / \mathrm{O}_{2}$ for $\mathrm{N} x-$ SCR CRABE SCUBA rebreather supplied with $T x: 24.0^{-0.5} \%_{v} \mathrm{O}_{2}: 35_{-1}^{+0} \%_{v} \mathrm{~N}_{2}: 41_{-0}^{+1} \%_{v} \mathrm{He}$

Trimix Tx: $24.0^{-0.5} \%_{v} \mathrm{O}_{2}: 35_{-1}^{+0} \%_{v} \mathrm{~N}_{2}: 41_{-0}^{+1} \%_{v} \mathrm{He}$

\begin{tabular}{|c|c|c|c|c|c|c|c|c|c|c|c|c|c|c|c|c|c|c|c|c|c|}
\hline \multirow{4}{*}{ Depth } & \multirow{4}{*}{$\begin{array}{l}\text { Time } \\
\text { spent } \\
\text { at the } \\
\text { bottom }\end{array}$} & \multirow{4}{*}{$\begin{array}{l}\text { Speed } \\
\text { of ascent } \\
\text { to the first } \\
\text { station }\end{array}$} & \multicolumn{9}{|c|}{$\begin{array}{l}\text { Decompression stations } \\
{\left[\mathrm{mH}_{2} \mathrm{O}\right]}\end{array}$} & \multirow{4}{*}{$\begin{array}{l}\text { Total } \\
\text { time } \\
\text { of } \\
\text { ompression (3) }\end{array}$} & \multicolumn{9}{|c|}{$\begin{array}{l}\text { Decompression stations } \\
{\left[\mathrm{mH}_{2} \mathrm{O}\right]}\end{array}$} \\
\hline & & & \multicolumn{5}{|c|}{$T x^{1}$} & \multicolumn{4}{|c|}{$T x^{(1)}\left(O_{2}{ }^{2}\right)$} & & 27 & 24 & 21 & $18 \quad 15$ & 12 & 9 & 6 & 3 & 0 \\
\hline & & & 27 & 24 & 21 & 18 & 15 & 12 & 9 & 6 & 3 & & \multirow{2}{*}{\multicolumn{9}{|c|}{ Gradient acc. to AMW $T x^{(1)}\left(O_{2}{ }^{(2)}\right)$}} \\
\hline & & & \multicolumn{9}{|c|}{ Time at the station } & & & & & & & & & & \\
\hline$\left[\mathrm{mH}_{2} \mathrm{O}\right]$ & {$[\mathrm{min}]$} & {$[\mathrm{min}]$} & & & & & & {$[\mathrm{min}]$} & & & & {$[\mathrm{min}]$} & \multicolumn{9}{|c|}{ [\%] } \\
\hline \multirow{14}{*}{80} & 5 & 4 & - & - & 2 & 2 & 3 & $3(1)$ & $4(1)$ & $6(2)$ & $14(3)$ & $49(29)$ & - & - & 82 & $93 \quad 98$ & $84(66)$ & $87(68)$ & $93(82)$ & $90(89)$ & $92(93)$ \\
\hline & $6(4)$ & 4 & - & - & 3 & 2 & 3 & $4(1)$ & $5(2)$ & $7(3)$ & $25(4)$ & $64(33)$ & - & - & 90 & 8390 & $99(73)$ & $93(82)$ & $94(86)$ & $94(84)$ & $87(94)$ \\
\hline & $7^{(5)}$ & 4 & - & 3 & 3 & 3 & 1 & (2) & (3) & (3) & $(8)$ & $(42)$ & - & 85 & 81 & $79 \quad 85$ & (93) & (91) & $(84)$ & (91) & (94) \\
\hline & $8^{(5)}$ & 4 & - & 3 & 3 & 3 & 3 & (2) & (3) & (4) & (11) & (47) & - & 90 & 85 & 8893 & (92) & (91) & (89) & (94) & (92) \\
\hline & 9(5) & 4 & - & 3 & 3 & 4 & 3 & (2) & (4) & (6) & (12) & (53) & - & 94 & 90 & $96 \quad 97$ & (96) & (95) & (90) & (93) & (93) \\
\hline & $10^{(5)}$ & 4 & 3 & 3 & 4 & 5 & 3 & (3) & (4) & $(8)$ & $(14)$ & (64) & 86 & 84 & 91 & $\begin{array}{ll}92 & 93 \\
\end{array}$ & (92) & $(90)$ & (92) & (94) & $(94)$ \\
\hline & $11^{5}$ & 4 & 3 & 4 & 4 & 5 & 4 & (3) & (5) & (9) & (16) & $(70)$ & 88 & 90 & 88 & $95 \quad 95$ & (92) & (92) & (93) & (95) & (93) \\
\hline & 5 & 4 & - & - & 2 & 2 & 3 & $3(1)$ & $4(1)$ & $20(5)$ & - & $49(29)$ & - & - & 82 & 9398 & $84(66)$ & $87(68)$ & $93(82)$ & $57(62)$ & $99(93)$ \\
\hline & $6^{(4)}$ & 4 & - & - & 3 & 2 & 3 & $4(1)$ & $5(2)$ & $32(7)$ & - & $64(33)$ & - & - & 90 & $83 \quad 90$ & $99(73)$ & $93(82)$ & $94(86)$ & $53(59)$ & $98(95)$ \\
\hline & $7^{(5)}$ & 4 & - & 3 & 3 & 3 & 1 & (2) & (3) & $(11)$ & - & $(42)$ & - & 85 & 81 & $79 \quad 85$ & (93) & (91) & $(84)$ & $(50)$ & $(94)$ \\
\hline & $8^{(5)}$ & 4 & - & 3 & 3 & 3 & 3 & (2) & (3) & (15) & - & $(47)$ & - & 90 & 85 & 8893 & (92) & (91) & (89) & (49) & (92) \\
\hline & 9 (5) & 4 & - & 3 & 3 & 4 & 3 & (2) & $(4)$ & $(18)$ & - & (53) & - & 94 & 90 & $96 \quad 97$ & (96) & (95) & $(90)$ & (46) & (93) \\
\hline & $10^{(5)}$ & 4 & 3 & 3 & 4 & 5 & 3 & (3) & (4) & $(22)$ & - & (64) & 86 & 84 & 91 & $92 \quad 93$ & (92) & $(90)$ & (92) & (43) & $(94)$ \\
\hline & $11^{(5)}$ & 4 & 3 & 4 & 4 & 5 & 4 & (3) & (5) & $(25)$ & - & $(70)$ & 88 & 90 & 88 & 9595 & (92) & (92) & (93) & $(42)$ & $(94)$ \\
\hline \multicolumn{22}{|c|}{$\begin{array}{l}\text { Compression speed } v \leq 30 \mathrm{mH}_{2} \mathrm{O} \cdot \mathrm{min}^{-1} \\
\text { Speed of transfer between stations } 3 \mathrm{mH}_{2} \mathrm{O} \cdot \mathrm{min}^{-1} \\
\text { (1) assumed value } \mathrm{O}_{2} \text { in } \mathrm{Tx} \text { in the circuit as } \geq 21 \% \mathrm{O}_{2} \\
\text { (2) assumed value of oxygen remaining in the circuit at the level of } 90 \% \mathrm{O}_{2} \\
\text { (3) compulsory } 3 \mathrm{~min} \text { oxygen ventilation ( } 3 \text { repetitions of triple exhalation into water and refill of the breathing space) of the breathing space before leaving the depth of } 15 \mathrm{mH} \mathrm{H}_{2} \mathrm{O} \\
\text { (in } \mathrm{Nx} \text { decompression triple ventilation is not applied), considered } 1 \mathrm{~min} \text { transition times between decompression stations with a single breathing space ventilation (triple } \\
\text { exhalation into water and refill of the breathing space) } \\
\text { (4) profile not recommended without additional oxygen XBS } \\
\text { (5) compulsory oxygen XBS }\end{array}$} \\
\hline
\end{tabular}


Example regular and emergency decompression table $T x / \mathrm{O}_{2}$ for $N x-S C R$ CRABE SCUBA rebreather supplied with $T x: 24.0^{-0.5} \%_{v} O_{2}: 35_{-1}^{+0} \%_{v} N_{2}: 41_{-0}^{+1} \%_{v} H e$

$$
\text { Trimix Tx: } 24.0^{-0.5} \%_{v} \mathrm{O}_{2}: 35_{-1}^{+0} \%_{v} N_{2}: 41_{-0}^{+1} \%_{v} H e
$$

\begin{tabular}{|c|c|c|c|c|c|c|c|c|c|c|c|c|c|c|c|c|c|c|c|c|c|c|}
\hline \multirow{4}{*}{ Depth } & \multirow{4}{*}{$\begin{array}{c}\text { Time } \\
\text { spent at } \\
\text { the } \\
\text { bottom }\end{array}$} & \multirow{4}{*}{$\begin{array}{l}\text { Speed } \\
\text { of ascent } \\
\text { to the first } \\
\text { station }\end{array}$} & \multicolumn{9}{|c|}{$\begin{array}{c}\text { Decompression stations } \\
{\left[\mathrm{mH}_{2} \mathrm{O}\right]}\end{array}$} & \multirow{4}{*}{$\begin{array}{c}\text { Total } \\
\text { time } \\
\text { of } \\
\text { decompression } 3\end{array}$} & \multicolumn{10}{|c|}{$\begin{array}{c}\text { Decompression stations } \\
{\left[\mathrm{mH}_{2} \mathrm{O}\right]}\end{array}$} \\
\hline & & & \multicolumn{5}{|c|}{$T x^{(1)}$} & \multicolumn{4}{|c|}{$T x^{11}\left(O_{2}{ }^{(2)}\right)$} & & 27 & 24 & 21 & 18 & 15 & 12 & 9 & 6 & 3 & 0 \\
\hline & & & 27 & 24 & 21 & 18 & 15 & 12 & 9 & 6 & 3 & & \multirow{2}{*}{\multicolumn{10}{|c|}{ Gradient acc. to AMW }} \\
\hline & & & \multicolumn{9}{|c|}{ Time at the station } & & & & & & & & & & & \\
\hline$\left[\mathrm{mH}_{2} \mathrm{O}\right]$ & {$[\mathrm{min}]$} & {$[\mathrm{min}]$} & & & & & & nin] & & & & {$[\mathrm{min}]$} & \multicolumn{10}{|c|}{ [\%] } \\
\hline & $12^{5}$ & 4 & 4 & 4 & 5 & 5 & 5 & (4) & $(6)$ & $(10)$ & $(16)$ & $(76)$ & 91 & 87 & 89 & 91 & 92 & $(90)$ & $(88)$ & (93) & $(92)$ & (94) \\
\hline & $13^{(5)}$ & 4 & 4 & 5 & 5 & 5 & 5 & (4) & $(8)$ & $(11)$ & $(16)$ & $(80)$ & 94 & 91 & 89 & 91 & 94 & $(94)$ & $(95)$ & $(92)$ & $(92)$ & $(95)$ \\
\hline & $14^{5}$ & 4 & 4 & 5 & 6 & 6 & 5 & (5) & $(8)$ & $(12)$ & $(17)$ & $(84)$ & 98 & 95 & 95 & 90 & 93 & $(94)$ & $(94)$ & $(94)$ & $(94)$ & (93) \\
\hline & 15 & 6 & 5 & 5 & 5 & 7 & 7 & (6) & (8) & (13) & (18) & (93) & 100 & 93 & 93 & 94 & 95 & (93) & $(92)$ & (93) & (94) & (93) \\
\hline
\end{tabular}

80

\begin{tabular}{|c|c|c|c|c|c|c|c|c|c|c|c|c|c|c|c|c|c|c|c|c|c|}
\hline $12^{5}$ & 4 & 4 & 4 & 5 & 5 & 5 & (4) & (6) & (26) & - & $(76)$ & 91 & 87 & 89 & 91 & 92 & $(90)$ & $(88)$ & (93) & $(43)$ & (95) \\
\hline $13^{5}$ & 4 & 4 & 5 & 5 & 5 & 5 & (4) & (8) & (27) & - & $(80)$ & 94 & 91 & 89 & 91 & 94 & (94) & (95) & (92) & (43) & (95) \\
\hline $14^{5}$ & 4 & 4 & 5 & 6 & 6 & 5 & (5) & (8) & (29) & - & $(84)$ & 98 & 95 & 95 & 90 & 93 & (94) & (94) & (94) & $(42)$ & (94) \\
\hline 15 & 6 & 5 & 5 & 5 & 7 & 7 & (6) & $(8)$ & (31) & - & (93) & 100 & 93 & 93 & 94 & 95 & (93) & (92) & (93) & $(40)$ & (93) \\
\hline
\end{tabular}

Compression speed $v \leq 30 \mathrm{mH}_{2} \mathrm{O} \cdot \mathrm{min}^{-1}$

Speed of transfer between stations $3 \mathrm{mH}_{2} \mathrm{O} \cdot \mathrm{min}^{-1}$

(1) assumed value $\mathrm{O}_{2}$ in $\mathrm{Tx}$ in the circuit as $\geq 21 \% \mathrm{O}_{2}$

(2) assumed value of oxygen remaining in the circuit at the level of $90 \% \mathrm{O}_{2}$

(3) compulsory $3 \mathrm{~min}$ oxygen ventilation ( 3 repetition of triple exhalation into water and refill of the breathing space) of the breathing space before leaving the depth of $15 \mathrm{mH}_{2} \mathrm{O}$ (in decompression $N x$ the triple ventilation is not applied), considered $1 \mathrm{~min}$ transition times between decompression stations with a single breathing space ventilation (triple exhalation into water and refill of the breathing space)

(4) profile not recommended without additional oxygen XBS

(5) compulsory oxygen XBS 
Calculations assumed that during oxygen decompression the content of $\mathrm{O}_{2}$ in the circuit would reach $C_{\mathrm{O}_{2}}^{\min } \geq 90 \%{ }_{O_{2}} / N_{2}$.

Although it is possible to design repeat dive procedures, the works on the decompression system for experimental dives did not deal with this issue as such dives are of little effectiveness already for the depth of $45 \mathrm{mH}_{2} \mathrm{O}$.

Within any given 24 hours it is not permitted to do more than one dive 10 with the use of the $T x-$ SCR CRABE SCUBA rebreather supplied with Tx: $24.0^{-0.5} \%_{v} \mathrm{O}_{2}: 35_{-1}^{+0} \%{ }_{v} \mathrm{~N}_{2}: 41_{-0}^{+1} \%_{v} \mathrm{He}$.

It is required that at least 24 hours elapses between consecutive dives, irrespective of the type of the dive preceding the one with the use of $T x-S C R$ CRABE SCUBA.

For the example decompression table presented as tab.1, oxygen decompression stations were implemented starting from $h=12 \mathrm{mH}_{2} \mathrm{O}$. Calculation of total decompression time was carried out with consideration of the time of reaching the first decompression station, ventilation of the breathing space with oxygen at the transition/station at $15 \mathrm{mH}_{2} \mathrm{O}$, as well as for the time transitioning between the stations.

The calculations contain oversaturation gradients established for algorithm $Z H L_{12}$ according to $B \ddot{h} \operatorname{lmann}$ with consideration of the ventilation model for the SCR CRABE SCUBA with Tx: $21 \%_{v} \mathrm{O}_{2}: 37 \%_{v} \mathrm{~N}_{2}$ : $42 \%{ }_{v}$ He remaining in the circuit ${ }^{11}$ [9].

\section{Experimental dives}

The experimental dives were carried out with the use of a rebreather in the configuration of TX - SCR CRABE SCUBA supplied with
Tx: $24.0^{-0} . \%_{v} \mathrm{O}_{2}: 35_{-1}^{+0} \%_{v} N_{2}: 41_{-0}^{+1} \%_{v} H e$ and a dosing nozzle with the output of $\dot{v}=17 \mathrm{dcm}^{3} \cdot \mathrm{min}^{-1}$, according to the experimental dive procedure as described above [16].

The basis for conducting the research were theoretical analyses ${ }^{12}$ which enabled the proposal of the diminished decompression regimes a seen in Table $8 \mathrm{FN}$, thus causing a significant extension of decompression procedure, although such an assumption is problematic to adopt for the use of Tx - SCR CRABE SCUBA in MCM and EOD operations in the Baltic $[13,14,16]$.

\section{General rules for the conduct of experiments}

The entire decompression procedure was implemented in water. Following a completed decompression the diver was monitored every 0.5 hour for a period of up to 3 hours ${ }^{13}$ with the use of intravascular free gas phase detection. The right and left subclavian vein and the right atrium of the heart were monitored.

Exceeding of the value grad $I I+$ for the atrial region or of grad $I I$ for subclavian veins constituted the premise for undertaking medical treatment. Any signs of pain or clinical symptoms typical of more severe cases of $D C^{14}$ constituted the premise to undertake immediate

medical treatment. Any decisions concerning the implementation of medical treatment in the case of any symptoms of $D C S$ were taken by the $D M O^{15}$.

Comprehensive summary of experimental dives conducted with the use of the TX - SCR CRABE SCUBA rebreather.

\begin{tabular}{|c|c|c|c|c|c|c|c|}
\hline \multirow{3}{*}{ No. } & \multirow{3}{*}{$\begin{array}{l}\text { Diver's } \\
\text { acronym }\end{array}$} & \multicolumn{5}{|c|}{ Diving procedure } & \multirow{3}{*}{$\begin{array}{l}\text { Comments and results of the test for } \\
\text { the presence of the free gas phase in } \\
\text { blood vessels [11]. }\end{array}$} \\
\hline & & Diving depth & $\begin{array}{l}\text { Time spent } \\
\text { at the } \\
\text { bottom }\end{array}$ & Speed & Diving time & $\begin{array}{l}\text { Decompressi } \\
\text { on time }\end{array}$ & \\
\hline & & {$\left[\mathrm{mH}_{2} \mathrm{O}\right]$} & {$[\mathrm{min}]$} & {$[a t a \cdot \sqrt{\min }]$} & {$[\mathrm{min}]$} & {$[\mathrm{min}]$} & \\
\hline 1 & Oskar & 60 & 10 & 22.14 & 42 & 32 & $\mathrm{G}=0 ; 24 \% \mathrm{O}_{2}$ \\
\hline 2 & Hotel & 60 & 10 & 22.14 & 44 & 34 & $\begin{array}{l}\mathrm{G}=0 ; 24 \% \mathrm{O}_{2} ; \text { lesser decompression } \\
\text { regime adopted with the distribution } \\
63 \mathrm{mH}_{2} \mathrm{O} / \\
\qquad / 10 \mathrm{~min}\end{array}$ \\
\hline 3 & Charlie & 63 & 10 & 23.08 & 44 & 34 & $\mathrm{G}=0 ; 24 \% \mathrm{O}_{2}$ \\
\hline 4 & Juliett & 66 & 10 & 24.03 & 51 & 41 & $\mathrm{G}=0 ; 24 \% \mathrm{O}_{2}$ \\
\hline 5 & Juliett & 69 & 10 & 24.98 & 56 & 46 & $\mathrm{G}=0 ; 24 \% \mathrm{O}_{2}$ \\
\hline 6 & Charlie & 60 & 10 & 22.14 & 43 & 33 & $\mathrm{G}=0 ; 24 \% \mathrm{O}_{2}$ \\
\hline 7 & Charlie & 72 & 10 & 25.93 & 63 & 53 & $\begin{array}{l}\text { after G=I- (LR); after } 1 \mathrm{~h} \mathrm{G}=\mathrm{I}-(\mathrm{LR}) \text {; } \\
\text { after } 2 \mathrm{~h} \mathrm{G}=\mathrm{I}-\text { (LR); after } 3 \mathrm{~h} \mathrm{G}=0 \text {; } \\
24 \% \mathrm{O}_{2}\end{array}$ \\
\hline 8 & Delta & 60 & 10 & 22.14 & 42 & 32 & $\mathrm{G}=0 ; 24 \% \mathrm{O}_{2}$ \\
\hline 9 & Charlie & 60 & 10 & 22.14 & 43 & 33 & $\mathrm{G}=0 ; 24 \% \mathrm{O}_{2}$ \\
\hline 10 & Kilo & 60 & 10 & 22.14 & 42 & 32 & $\begin{array}{l}\text { after } \mathrm{G}=\mathrm{I}-(\mathrm{OS}) \text { and } \mathrm{G}=\mathrm{I}(\mathrm{LR}) \text {; after } \\
30 \mathrm{~min} \mathrm{G}=\mathrm{I}(\mathrm{LR}) \text {; after } 1 \mathrm{~h} \mathrm{G}=\mathrm{I}-(\mathrm{LR}) \text {; } \\
\text { after } 2 \mathrm{~h} \mathrm{G}=0 ; 24 \% \mathrm{O}_{2}\end{array}$ \\
\hline 11 & Juliett & 60 & 10 & 22.14 & 42 & 32 & $\mathrm{G}=0 ; 24 \% \mathrm{O}_{2}$ \\
\hline 12 & Kilo & 66 & 10 & 24.03 & 53 & 43 & $\mathrm{G}=0 ; 24 \% \mathrm{O}_{2}$ \\
\hline 13 & Charlie & 69 & 10 & 24.98 & 56 & 46 & $\begin{array}{l}\text { after G=I (PR); G=0 after 30min; } \\
24 \% \mathrm{O}_{2}\end{array}$ \\
\hline
\end{tabular}


Comprehensive summary of experimental dives conducted with the use of the TX - SCR CRABE SCUBA rebreather.

\begin{tabular}{|c|c|c|c|c|c|c|c|}
\hline \multirow{3}{*}{ No. } & \multirow{3}{*}{$\begin{array}{l}\text { Diver's } \\
\text { acronym }\end{array}$} & \multicolumn{5}{|c|}{ Diving procedure } & \multirow{3}{*}{$\begin{array}{l}\text { Comments and results of testing for } \\
\text { the presence of the free gaseous } \\
\text { phase in blood vessels (Kłos R., } \\
\text { 2012a) }\end{array}$} \\
\hline & & Diving depth & $\begin{array}{lr}\text { Time spent } \\
\text { at the } \\
\text { bottom }\end{array}$ & Speed & Diving time & $\begin{array}{l}\text { Decompressi } \\
\text { on time }\end{array}$ & \\
\hline & & {$\left[\mathrm{mH}_{2} \mathrm{O}\right]$} & {$[\mathrm{min}]$} & {$[a t a \cdot \sqrt{\min }]$} & {$[\mathrm{min}]$} & {$[\mathrm{min}]$} & \\
\hline 14 & Kilo & 63 & 10 & 23.08 & 43 & 33 & $\mathrm{G}=0 ; 24 \% \mathrm{O}_{2}$ \\
\hline 15 & Foxtrot & 60 & 10 & 22.14 & 43 & 33 & $\mathrm{G}=0 ; 24 \% \mathrm{O}_{2}$ \\
\hline 16 & Juliett & 72 & 10 & 25.93 & 61 & 51 & $\begin{array}{l}\text { after } G=I-(O S) \text { and } G=I(L R) \text { and } G=I+ \\
(P R) ; \text { after } 30 \mathrm{~min} G=I(L R) \text { and } G=I \\
(P R) \text {; after } 1 \mathrm{~h} \mathrm{G=I} \mathrm{(LR)} \mathrm{and} G=I-(P R) \text {; } \\
\text { after } 2 \mathrm{~h} \quad G=I-(L R) \text {; after } 3 \mathrm{~h} G=0 \text {; } \\
24 \% \mathrm{O}_{2}\end{array}$ \\
\hline 17 & Foxtrot & 66 & 10 & 24.03 & 52 & 42 & $\mathrm{G}=0$ \\
\hline 18 & Charlie & 75 & 10 & 26.88 & 70 & 60 & $\begin{array}{l}\text { after } \mathrm{G}=\mathrm{I}-(\mathrm{LR}) \text {; after } 30 \mathrm{~min} \mathrm{G}=\mathrm{I}-(\mathrm{LR}) \\
\text { and } \mathrm{G}=\mathrm{I}-(\mathrm{OS}) \text {; after } 1 \mathrm{~h} \mathrm{G}=\mathrm{I}(\mathrm{LR}) \text { and } \\
\mathrm{G}=\mathrm{I}-(\mathrm{OS}) \text {; after } 2 \mathrm{~h} \mathrm{G}=0 ; 24 \% \mathrm{O}_{2}\end{array}$ \\
\hline 19 & Kilo & 72 & 10 & 25.93 & 62 & 52 & $\begin{array}{l}\text { after } \mathrm{G}=\mathrm{I}(\mathrm{OS}) \text { and } \mathrm{G}=\mathrm{I}(\mathrm{LR}) \text { and } \mathrm{G}=\mathrm{II}+ \\
(\mathrm{PR}) \text {; after } 30 \mathrm{~min} \mathrm{G}=\mathrm{I}-(\mathrm{OS}) \text { and } \mathrm{G}=\mathrm{II} \\
(\mathrm{LR}) \text { and } \mathrm{G}=\mathrm{II}+(\mathrm{PR}) \text {; after } 1 \mathrm{~h} \mathrm{G}=\mathrm{I}-\mathrm{-} \\
(\mathrm{OS}) \text { and } \mathrm{G}=\mathrm{II}(\mathrm{LR}) \text { and } \mathrm{G}=\mathrm{II}(\mathrm{PR}) \text {; } \\
\text { after } 2 \mathrm{~h} \mathrm{G}=\mathrm{I}+(\mathrm{LR}) \text { and } \mathrm{G}=\mathrm{II}-(\mathrm{PR}) \text {; } \\
\text { Ventilation with oxygen } 6 \mathrm{~m} / 30 \mathrm{~min} \\
\mathrm{G}=0 ; 24 \% \mathrm{O}_{2}\end{array}$ \\
\hline 20 & Juliett & 63 & 10 & 23.08 & 43 & 33 & $\begin{array}{l}\text { after } \mathrm{G}=\mathrm{I}(\mathrm{LR}) ; \text { after } 30 \mathrm{~min} \mathrm{G}=\mathrm{I}(\mathrm{LR}) \text {; } \\
\text { after } 1 \mathrm{~h} \mathrm{G} \mathrm{G}=0 ; 24 \% \mathrm{O}_{2}\end{array}$ \\
\hline 28 & Lima & 80 & 10 & 28.46 & 77 & 67 & $\mathrm{G}=0 ; 23.5 \% \mathrm{O}_{2}$ \\
\hline 29 & November & 60 & 15 & 27.11 & 70 & 55 & $\begin{array}{l}\text { after } 30 \mathrm{~min} G=\mathrm{II}(\mathrm{PR}) \text { and } \mathrm{G}=\mathrm{I}-(\mathrm{OS}) \\
\text { and (LR); after } 1 \mathrm{~h} \mathrm{G}=\mathrm{I}(\mathrm{PR}) \text { and } \mathrm{G}=\mathrm{I}- \\
(\mathrm{LR}) \text {; after } 2 \mathrm{~h} \mathrm{G}=0 ; 23.5 \% \mathrm{O}_{2}\end{array}$ \\
\hline 30 & Mike & 80 & 12 & 31.18 & 88 & 76 & $\mathrm{G}=0 ; 23.5 \% \mathrm{O}_{2}$ \\
\hline 31 & November & 65 & 12 & 25.98 & 62 & 50 & $\begin{array}{l}\text { after } G=I+(P R) \text { and } G=I(L R) ; \text { after } \\
30 \text { min } G=I I(P R) \text { and } G=I \text { (LR); after } \\
1 \mathrm{~h} G=I I(P R) \text { and } G=I(L R) ; \text { after } 2 \mathrm{~h} \\
\mathrm{G}=\mathrm{I}(\mathrm{PR}) \text { and } \mathrm{G}=\mathrm{I}-(\mathrm{LR}) \text {; after } 3 \mathrm{~h} \mathrm{G}=0 \text {; } \\
23.5 \% \mathrm{O}_{2}\end{array}$ \\
\hline
\end{tabular}

$T x$ exposures were treated as passive descents since during their course divers did not engage in any considerable effort. Divers maintained activity allowing them to simulate normal loading during passive descents and ascents, an increase in activity only being permitted for the purpose of preserving thermal comfort.

As routine activities must be balanced with the possibility of the development of an emergency situation, the experiments allowed for the undertaking of additional exertion. Simulation of emergency situations consisting of additional effort output was consented by the $D M O$.

At the time of reaching the first decompression station and during the stay at decompression stations the load was minimal. The effort control station has been already described and will not be analysed here $[9,12]$.

Example decompression distributions are presented in tab. $1[14,13,16]$.

The table is divided to encompass regular procedures as well as those applied in emergency situations ${ }^{16}$ such as during situations of deteriorating weather conditions and rapidly increasing wave activity. In such circumstances it is difficult for a diver to remain at the $3 \mathrm{mH}_{2} \mathrm{O}$ station, hence decompression should be completed at the deeper6 $\mathrm{mH}_{2} \mathrm{O}$ station.

The discussed phase of tests included only one experimental dive of this type - tab. 2 .

Compliance control of decompression assumptions with currently performed decompression was based on monitoring of the composition of the breathing mix exhaled by the diver. It was aimed to maintain the oxygen content $C_{O_{2}}$ in the entire diving procedure of the $T x$ exhaled by the diver at the level of $C_{O_{2}} \geq 20 \%{ }_{v} O_{2} / T x$. If the said conditions were not maintained during the stay at the depth, the breathing space of the rebreather would be subjected to ventilation, however during the course of these experimental dives, there was no need for an emergency interruption of the decompression procedure.

Securing divers followed standard $T x$ decompression procedures [19].

\section{DISCUSSION}

$\underline{\text { Results of experimental dives }}$ 
The objective of the research was to conduct verification of the above decompression assumptions. To this end, 31 dives were performed with the use of the premix $T x 24.0 \% \mathrm{O}_{2} / \mathrm{N}_{2}+\mathrm{He}$ and $\mathrm{Tx} 23.5 \% \mathrm{O}_{2} / \mathrm{Tx}$ and an injector with the capacity of $\dot{v}=17 \mathrm{dcm}^{3} \cdot \mathrm{min}^{-1}$ within the depth range of $H \in[60 ; 80] \mathrm{mH}_{2} \mathrm{O}$ and a stay time between $\tau \in[10 ; 15] \mathrm{min}$ and the load shaped by the divers in such a way to ensure oxygen content $C_{\mathrm{O}_{2}}$ to be not less than $C_{\mathrm{O}_{2}}>20 \%{ }_{v} \mathrm{O}_{2} / \mathrm{N}_{2}-$ fig. 3 .
The average load for such dives, expressed in the pressure force $F$ seen to be exerted on the horizontal plate connected to a strain gauge, was at the level of $F \in$ $=[0.7 ; 2.3] k G$. At first approximation we may assume that the average observed pressure corresponds to the speed of swimming expressed in knots $v \in[0.5 ; 0.8] k$ $[9,12,14]$.

The time of maintained load oscillated between $t \in[2,5 ; 15] \mathrm{min}$.
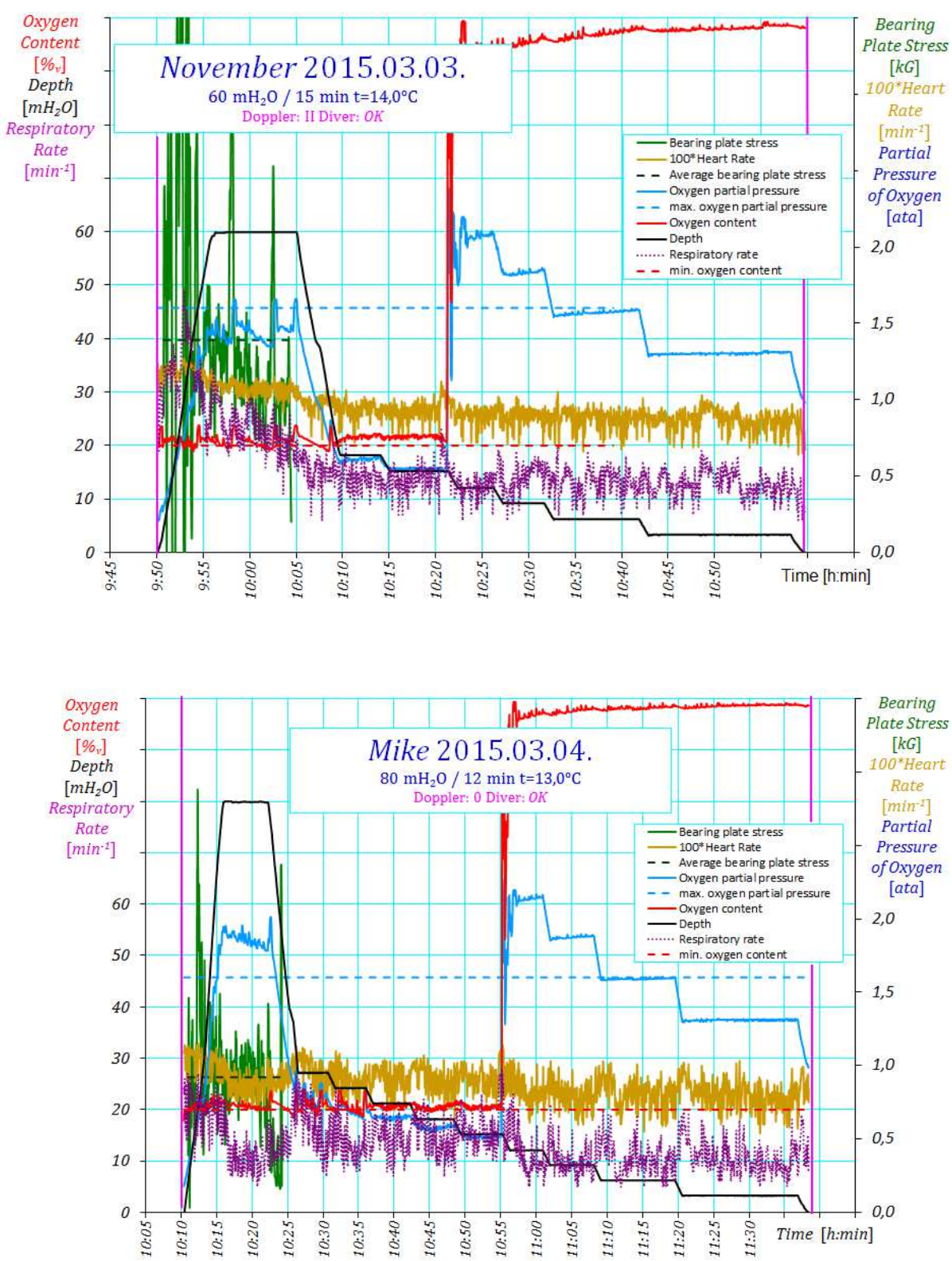

Fig. 3. Example results of experimental dives conducted with the use of the Tx-SCR CRABE SCUBA rebreather.

The scope of water temperatures during particular dives was between $t \in[10 ; 22]^{\circ} \mathrm{C}$.

In the experimental dives decreases in minimal oxygen content $C_{O_{2}}$, non-compliant with the adopted assumptions, below the level of $C_{O_{2}}=21 \%{ }_{v} O_{2} / T x$ were observed in the time span of $t \geq 1 \mathrm{~min}$. During short periods of time, the observable decreases were below the value of $C_{\mathrm{O}_{2}}=20 \%{ }_{v} \mathrm{O}_{2} / \mathrm{N}_{2}$.

During the free gas phase, maximum values measured in blood vessels of the precordial area or in the region of the right or left subclavian vein were obtained via monitoring and found to be within Doppler $\in[0 ; I I+]$. 
a)

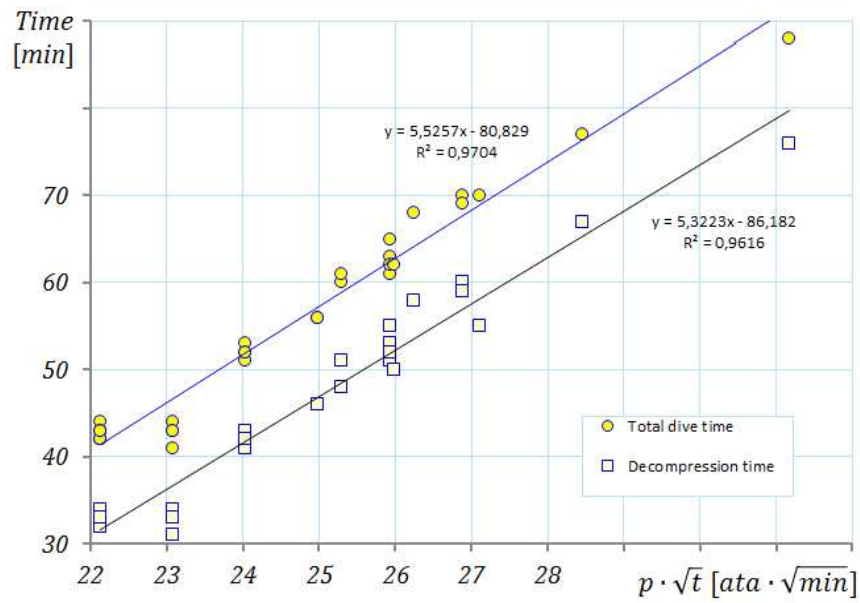

b)

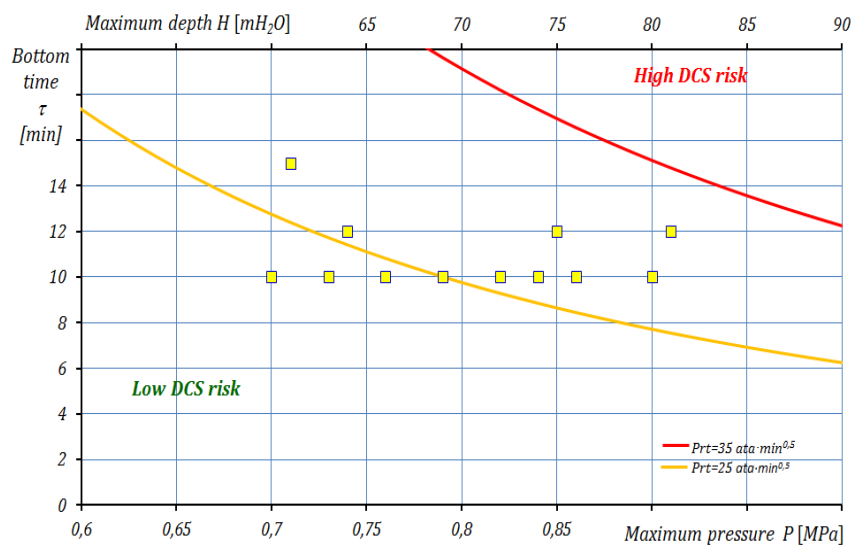

Fig. 4. Decompression load rate Prt for: a) performed experimental dives; b) performed types of experimental dives

A collective summary of results for the 31 experimental dives with the use of the TX - SCR CRABE SCUBA rebreather are shown in tab. 2 and fig. 3. Measurement results indicate that at each attempt with an increased effort the oxygen content $C_{O_{2}}$ in the inhaled $T x$ was seldom below the minimal oxygen content $C_{O_{2}} \geq 20 \%{ }_{v} O_{2} / T x$, and relatively frequently below $\mathrm{C}_{\mathrm{O}_{2}} \geq 21 \%{ }_{v} \mathrm{O}_{2} / \mathrm{Tx}$.

\section{$\underline{\text { Decompression load rate }}$}

Based on diffusion process theory, Hempelman derived a rule referred to as Prt [16]. This model assumes a constant value of the product of pressure $p$ and root of time $\tau$ : Prt $=p \cdot \sqrt{\tau}$ based on an analysis of diffusion process, which checks out well with short exposure times ${ }^{17}[3]$.

The value of the product Prt is sometimes used as a decompression load rate [6].

Moderate hazard values are those for which Prt $<25 \mathrm{ata} \cdot \mathrm{min}^{0.5}$, whereas the average

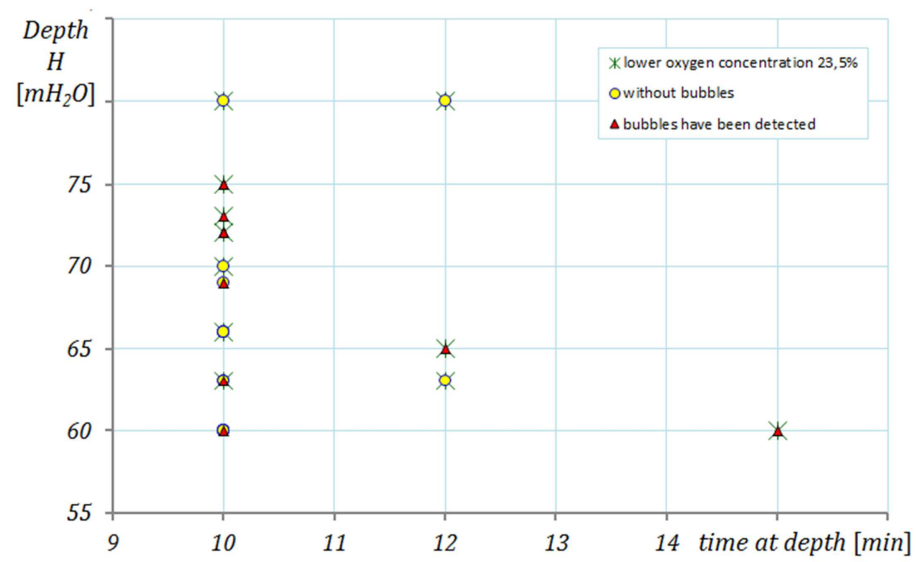

Fig. 5. Measured results for the occurrence of free gas phases in blood vessels during the conducted experimental dives are depicted in a graph of function of the planned depth $H$ and the planned stay time at the bottom $\tau: H=f(\tau)$, depending on oxygen concentration in the inert as a parameter. 


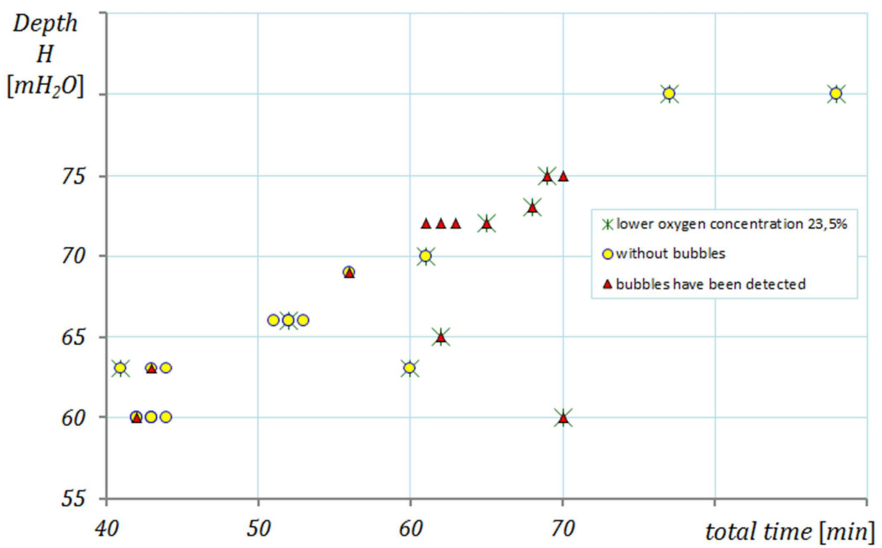

Fig. 6. Measured results for the occurrence of free gas phases in blood vessels during the conducted experimental dives are depicted in a graph of function of the planned depth $H$ and the real diving time $T: H=f(T)$, depending on oxygen concentration in the inert as a parameter.

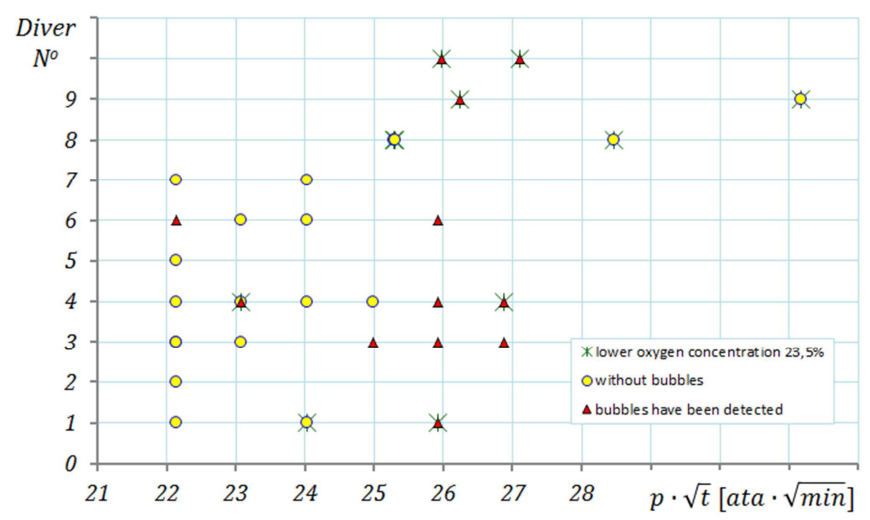

Fig. 7. Measured results for the occurrence of free gas phases in blood vessels during the conducted experimental dives for the dependence of particular experimental divers on decompression load Prt, depending on oxygen concentration in the inert as a parameter.

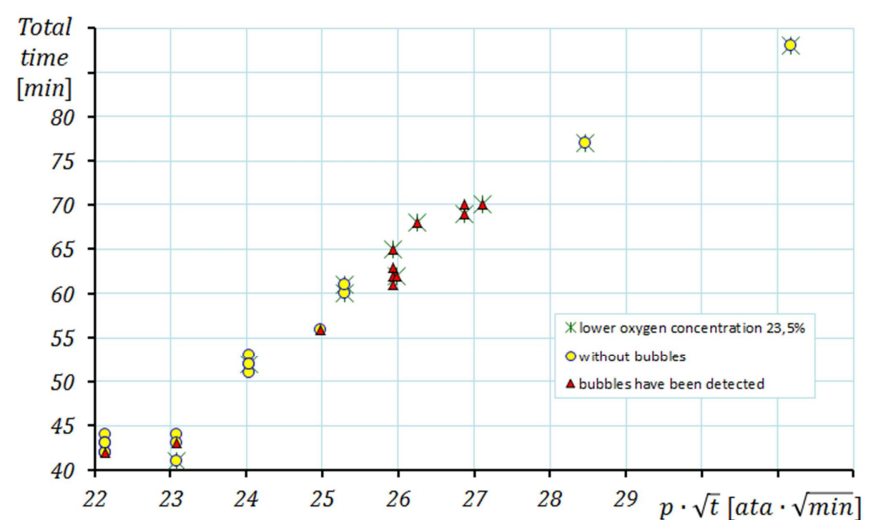

Fig. 8. Measured results for the occurrence of free gas phase in blood vessels during the conducted experimental dives depicted in a graph of real diving time $T$ in the function of decompression load Prt, depending on oxygen concentration in the inert as a parameter.

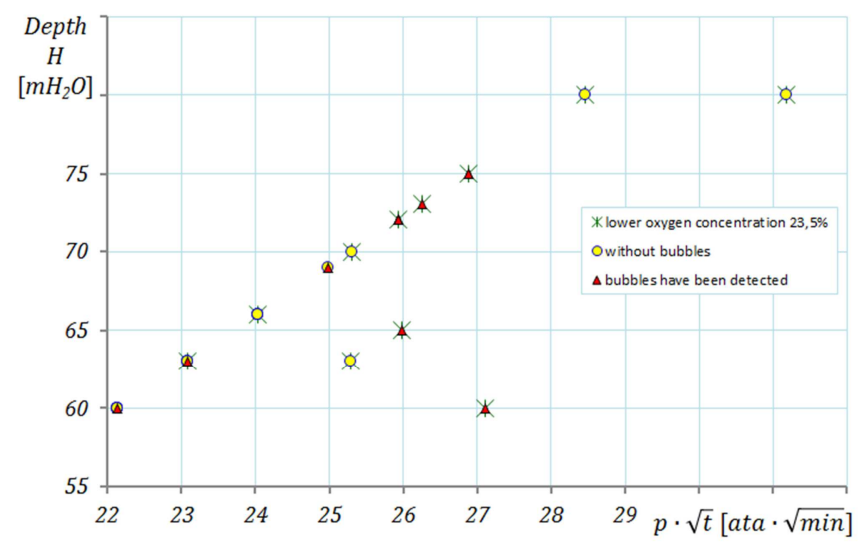

Fig. 9. Measurement results for the occurrence of free gas phases in blood vessels in the conducted experimental dives plotted on the dependence of the planned diving depth $H$ on decompression load Prt, depending on oxygen concentration in the inert as a parameter for 25 ata $\cdot$ min $^{0.5}<P r t \leq 35$ ata. $\min ^{0.5}$, and significant hazard values for product $\operatorname{Prt}>35 \mathrm{ata} \cdot \mathrm{min}^{0.5}[7]$. 
This principle was used in the risk assessment of $D C S$ at the North Sea commissioned by the British Department of Energy [17,3,7]. Here, this rule is used in the assessment of the decompression load - fig. 4 .

\section{Analysis of results}

The study consisted in 31 experimental dives, 20 with the use of Tx:24.0\% ${ }_{v} \mathrm{O}_{2}: 35.0 \%_{v} \mathrm{~N}_{2}: 41.0 \%{ }_{v} \mathrm{He}$ mixture, and 11 with $T x: 23.5 \%_{v} \mathrm{O}_{2}: 35.0 \%_{v} \mathrm{~N}_{2}$ : $41.0 \%{ }_{v} \mathrm{He}$. The presence of a free gas phase in blood vessels was diagnosed in 12 dives, with all measurements concerned with the "silent gas phase" [11]. In one case, due to a persistent free gas phase it was decided to perform ventilation with pressurised oxygen.

Measured results for the occurrence of free gas phases in blood vessels in the conducted experimental dives are depicted in the graph representing the function of the planned depth $H$ and the planned stay time at the bottom $\tau: H=f(\tau)$, depending on oxygen concentration in the inert as a parameter - fig.5.

Fig. 6, on the other hand, depicts measurement results for the occurrence of free gas phases in blood vessels in the conducted experimental dives in the function of the planned depth $H$ and the real diving time $T: H=f(T)$, depending on oxygen concentration in the inert as a parameter.

Graph analysis indicates that oxygen concentration reduction did not have an immediate effect on result deterioration. Nonetheless, fig. 6 shows a grouping of diving results with the diagnosed presence of a free gas phase in blood vessels in the central part of the graph. It is possible that the factor responsible for this fact is a change in the main tissue for these decompression distributions for which inadequate parameters had been selected.

It is common belief, that algorithm $Z H L_{12}$ is not safe for recreational dives, however it was applied here due to the fact that military dives allow for the possibility of accepting higher risk values for DCS occurrence [4]. Military divers are preselected, trained, and their health, physical condition and efficiency are constantly monitored. This facilitates the scheduling of less conservative decompression programmes ${ }^{18}$, thus presenting an advantage over to less prepared opponents and ensuring greater effectiveness of the conducted MCM and $E O D$ operations.

Measured results for the occurrence of free gas phases in blood vessels were obtained by the conduction of the previously mentioned experimental dives. Seeking to determine the dependence of decompression load Prt on oxygen concentration $C_{\mathrm{O}_{2}}$ in the inert for particular experimental divers, the results of these dives were shown as a parameter.

It is noted that divers' reactions are commonly compliant with the expectation of an occurrence of a free gas phase in dives characterised by a higher hazard expressed as Prt product - fig. 7. Moreover, we may find several instances of differing behaviour, which suggests the significance of diver preselection and their training to perform deep dives. It would be also advisable to search for interactions between their physical and physiological parameters ${ }^{19}$ and the observed phenomena.

Fig. 8 depicts measurement results for the occurrence of free gas phases in blood vessels in the conducted experimental dives as a graph showing the relationship between real diving time $T$ in the function of decompression load Prt, depending on oxygen concentration in the inert $C_{\mathrm{O}_{2}}$, as a parameter.

Fig. 9, on the other hand, represents measured results for the occurrence of free gas phases in blood vessels in the conducted experimental dives plotted on the dependence of the planned diving depth $H$ on the decompression load Prt, depending on oxygen concentration in the inert $C_{\mathrm{O}_{2}}$ as a parameter.

Both graphs, similarly to the previous ones, demonstrate the possibility of an occurrence of inadequately selected parameters for the main tissues for average hazard distributions for the occurrence of $D C S$.

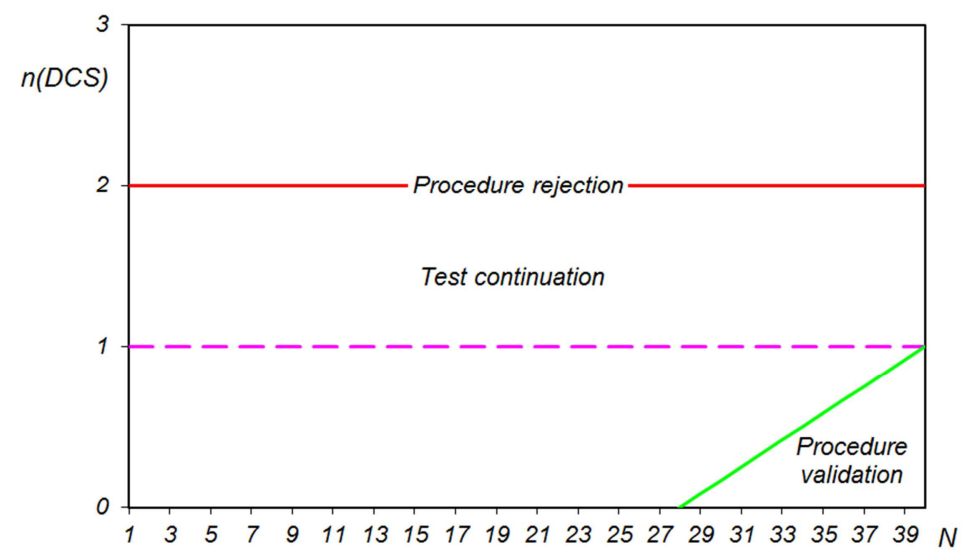

Fig. 10. Validation procedure diagram prepared at the NMRI for a group of decompression profiles treated as a block [5]. 
Probability of a statistical occurrence of combined incidents for the NMRI validation procedure

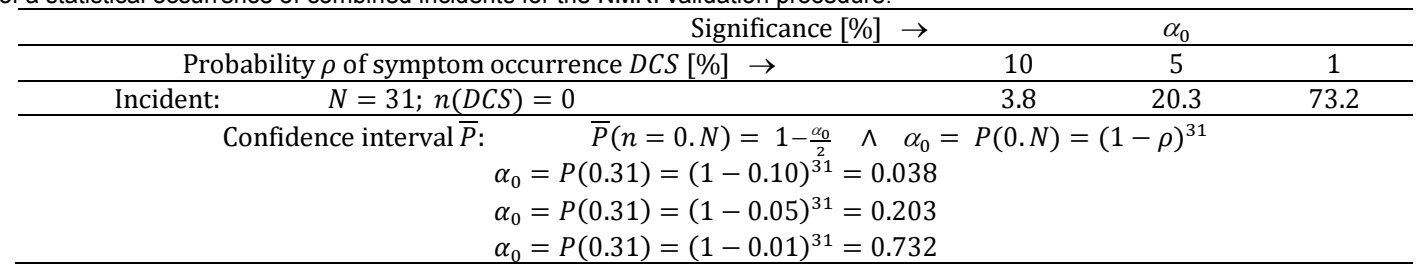

\section{Conclusions}

Following the performance of 31 dives without the occurrence of $D C S$ symptoms it is possible to accept the proposed decompression tables in concord with NMRI procedure - fig. 10 [15].

By analysis of the results obtained on the basis of binomial distribution, we may stipulate that the maximum expected probability of an occurrence of $D C S$ symptoms while utilising the system does not exceed $10 \%$ for the significance level of $\alpha_{0}>0.05$. The probability of accidental occurrences of combined incidents, in the function of probability of occurrence of a single DCS incident is shown in tab. 3. For NMRI procedure it is possible to adopt zero $H_{0}$ and alternative $H_{1}$ hypotheses in the following form:

$$
\forall_{0 \leq \rho_{0} \leq 1}\left\{\begin{array}{l}
H_{0}: \rho<10 \% \\
H_{1}: \rho \geq 10 \%
\end{array}\right.
$$

where: $\rho$-DCS threat expressed as probability of its occurrence; $H_{0}$-zero hypothesis; $H_{1}$-alternative hypothesis.

The calculated significance of this inference amounts to ${ }^{20}: \alpha_{0}=P(0.31)=(1-0.10)^{1}=0.038$ and is lower than $5 \%{ }^{21}$. Numerical solutions for the system of equations for critical significance values $\alpha_{k}$ and power of inference $\beta_{k}[8]$ :

$$
\begin{gathered}
1-\sum_{x=0}^{N}\left[\frac{N !}{x ! \cdot(N-x)} \cdot \rho_{1}^{x} \cdot\left(1-\rho_{1}\right)^{N-x}\right]=\beta_{k} \\
\sum_{x=0}^{N}\left[\frac{N !}{x ! \cdot(N-x)} \cdot \rho_{0}^{x} \cdot\left(1-\rho_{0}\right)^{N-x}\right]=\alpha_{k}
\end{gathered}
$$

where: $\rho_{0}$-left limit of confidence interval for hazard values expressed with the probability of DCS symptoms occurrence; $\rho_{1}$ - right limit of confidence interval for hazard values expressed with the probability of DCS symptoms occurrence; $\alpha_{k}-$ critical value of the significance of inference; $\beta_{k}$ - critical value of the power of inference; $N$ - number of dives.

with regard to $\rho_{0}$ and $\rho_{1}$ for $N=31$ experimental dives, $n=0$ observed cases of DCS occurrence, critical significance value of inference at the level of $\alpha_{k}=0.05$ and the assumption of the critical value of the power of inference at the level of $\beta_{k}=0.95$, we may calculate the values of hazard DCS: $\rho_{0} \cong 0.092 ; \rho_{1} \cong 0.092$. The confidence interval for the thus calculated threat levels equals $\rho \in[0 ; 0.092]$.

In conclusion, since the profile underwent successful validation for $N=31$ experimental dives with $n=0$ cases of $D C S$, there are no grounds for rejection of the zero hypothesis $H_{0}: \rho<10 \%$ at the confidence level of $\bar{P}=95 \%$ and inference power of $\beta \geq 0.95$.

It would seem however that the response following the implementation of the NMRI procedure is not satisfactory enough. Nonetheless, we should note that threat determination for $D C S$ at the level of $1 \%$ requires conducting $\quad N=\frac{\log \alpha_{0}}{\log \left(1-\rho_{0}\right)}=\frac{\log 0.05}{\log (1-0.01)}>298$ experimental dives with $n=0$ cases of $D C S$. We may also indicate that it is required to carry out $N>473$ experimental dives for $n=1$ cases of $D C S$ in order to ensure that the risk of $D C S$ occurrence remains at the said level.

The inference was based on the NMRI procedure, as the experimental dives were not aimed at proving legitimacy of the decompression model since it had already been validated by Bühlmann. What was tested were the system assumptions for the utilisation of 22 the rebreather. The tests are of a screening character, with the purpose of eliminating possible gross errors. It appears sufficient to obtain the substantiation that the threat of $D C S$ is below $\rho<10 \%$, with the confidence interval of $\bar{P}=95 \%$ and the power of inference of $\beta \geq 0.95$, in order to make certain that gross errors were avoided in the process of decompression planning ${ }^{23}$.

\section{Conclusions}

Series I encompassed 31 experimental dives carried out for the purpose of testing a diving system with the use of the Tx-SCR CRABESCUBA rebreather supplied with $T x: 24.0^{-0.5} \%{ }_{v} \mathrm{O}_{2}: 35_{-1}^{+0} \%_{v} N_{2}: 41_{-0}^{+1} \%_{v} \mathrm{He}$ and a dosing nozzle with the output of $\dot{v}=17 \mathrm{dcm}^{3}$. $\mathrm{min}^{-1}$ within the scope of maximum diving depths of $\mathrm{H}^{\max } \in[60 ; 80] \mathrm{mH}_{2} \mathrm{O}$.

During these experiments, we applied our own ventilation model to the assumptions relating to the apparatus's breathing space, our method differing from the one used by the designers to develop their assumptions for this breathing system [2]. The said model is compatible with the model described in the literature [18]. The ventilation model had been described earlier and was not analysed here [4].

Decompression tables for the Tx $23 \% \mathrm{O}_{2} 36 \% \mathrm{~N}_{2} 41 \% \mathrm{He}-\mathrm{SCR}$ CRABE SCUBA system according to Bühlmann's approach were proposed with certain modifications. The said approach is fundamentally compliant with theAbyss algorithm - 100. It was attempted to propose the possibility of an emergency omission of the last station at $3 \mathrm{mH}_{2} \mathrm{O}$ and finish decompression at $6 \mathrm{mH}_{2} \mathrm{O}$ in the case of a considerable increase in the wave motion in the vicinity ${ }^{24}$.

In the proposed decompression system it was possible to apply decompression stations ${ }^{25}$ and procedures reducing the time taken to reach the first of the stations ${ }^{26}$ traditionally used according to decompression tables followed by the Polish Navy.

The experimental dives did not test the decompression model, as it had already been validated by Bühlmann, but rather system assumptions for the use of the rebreather ${ }^{27}$. The tests are of a screening character, with the purpose of eliminating possible gross errors.

For this purpose it seems sufficient that the threat of $D C S$ was estimated for the level of ca. $\rho \cong 0.092$, with a confidence interval of $\bar{P}=95 \%$ and inference power at $\beta \geq 0.95$. Research results show that probably 
no gross error had been made, otherwise the threat $\rho$ would be much higher. Following the performance of 31 dives without the occurrence of DCS symptoms it is possible to accept the proposed decompression tables in concord with the NMRI [15] procedure.

The time limits for the descent and stay at the bottom for up to $10 \mathrm{~min}$ are too short for operations undertaken in the Baltic. The mediocre visibility and darkness experienced at depths exceeding $30 \mathrm{mH}_{2} \mathrm{O}$ require the diver to approach a mine-resembling object to the proximity of up to $0.5 \mathrm{~m}$ for reconnaissance.

With a maximum speed of descent of $15 \mathrm{mH}_{2} \mathrm{O} \cdot \mathrm{min}^{-1}$, this allows divers to descend to the depths included in the range between $\mathrm{H} \in[60 ; 80] \mathrm{mH}_{2} \mathrm{O}$ within $5 \mathrm{~min}$. Therefore, the remaining time for reconnaissance and decompression commencement reaches approximately $3 \mathrm{~min}$.

\section{Guidelines for follow-up research}

The results of the experimental dives utilising the TX-SCR CRABE SCUBA rebreather show that at each attempt to increase an effort, the oxygen content $C_{\mathrm{O}_{2}}$ in the inhaled $T x$ rarely dropped below the defined minimum oxygen content of $\mathrm{C}_{\mathrm{O}_{2}} \geq 20 \%{ }_{v} \mathrm{O}_{2} / \mathrm{N}_{2}$. Hence, further research should adopt this value for the purpose of calculating decompression distribution rather than the previously adopted value of $C_{\mathrm{O}_{2}} \geq 21 \%{ }_{v} \mathrm{O}_{2} / \mathrm{N}_{2}$.

On the basis of results of the conducted tests it was proposed to modify the decompression system towards more conservative profiles ${ }^{28}$. For this purpose, oversaturation gradients were estimated at the level of $\delta^{\max } \leq 95 \%$ during the decompression process and $\delta^{\max } \leq 90 \%$ on decompression completion.

The calculations were based on the minimal value of oxygen concentration remaining in circulation within the breathing mix at the level of $C_{O_{2}}^{\min } \geq$ $20 \%{ }_{v} O_{2} / T x$. Moreover, the rebreather ventilation procedure was modified. In the calculation of decompression tables, nitrogen times for theoretical tissues were used in compliance with the system $Z H L_{12}$.

It was assumed that in the 10 minutes prior to making the descent, the diver had been breathing with $T x$ from the apparatus on the surface.
It was proposed to extend the scope of operational depths $\mathrm{H} \in[45 ; 80] \mathrm{mH}_{2} \mathrm{O}$ to cover the operational depths of $\mathrm{Nx}$. Oxygen decompression stations were applied starting at $12 \mathrm{mH}_{2} \mathrm{O}$, however triple ventilation of the circuit with oxygen was conducted already at the station at $15 \mathrm{mH}_{2} \mathrm{O}$ prior to departure or in the passing of this depth.

Triple ventilation of the breathing space with oxygen consists in triple repetition of a single ventilation procedure involving triple exhalation of the breathing mix from the lungs into the water and supplementation of the breathing space with oxygen.

In the absence of the $15 \mathrm{mH}_{2} \mathrm{O}$ station, the oxygen supply is activated at the depth of $15 \mathrm{mH}_{2} \mathrm{O}$, whereas breathing space ventilation with oxygen occurs in the ascent to the first decompression station below the depth of $15 \mathrm{mH}_{2} \mathrm{O}$. The speed of reaching the first station was defined as $\dot{v}<15 \mathrm{mH}_{2} \mathrm{O} \cdot \mathrm{min}^{-1}$.

In oxygen decompression, at the time of transition between stations with the speed of $\dot{v}<3 \mathrm{mH}_{2} \mathrm{O} \cdot \mathrm{min}^{-1}$ the breathing space is no longer ventilated as tests showed that in the course of $T x$ and $O_{2}$ decompression such ventilation is not necessary, although still recommended.

Calculations assumed that during oxygen decompression the content of $C_{O_{2}}$ in the circuit will reach $C_{O_{2}}^{\min } \geq 90 \%{ }_{O_{2}} / T x$. The speed of reaching the first station was defined as $\dot{v} \leq 15 \mathrm{~m} \cdot \mathrm{min}^{-1}$.

Although it is possible to design repeat dive procedures, the works on the decompression system for experimental dives did not deal with this issue as such dives are of little effectiveness already at the depth of 45 $\mathrm{mH}_{2} \mathrm{O}$. Within any given 24 hour period only one dive 29 was permitted to take place with the use of the $T x-S C R$ CRABE SCUBA rebreather supplied with premix of the following composition: $T x$ : $23.0^{+0.5} \%_{v} O_{2}$ : $36_{-1}^{+0} \%_{v} N_{2}: 41_{-0}^{+1} \%_{v} \mathrm{He}$.

The research on the diving apparatus CRABE is a result of a scientific project financed from research funds obtained from the National Centre for Research and Development in 2012-2015.

\section{BIBLIOGRAPHY}

1. Aqua Lung France. 2012. Dive conduct and organization. Nice : Aqua Lung France, 2012. Ref. 490047 A - Ed 16/07/12 - AQUA LUNG - Dive Conduct and Organization. CRABE Apparatus.

2. Aqua Lung. 2004. User manual CRABE. Nice : Aqua Lung France, 2004. provisional version 1.12. 2004.

3. Ashida H., Ikeda T., Tikuisis P., Nishi R.Y. 2005. Relationship between two different functions derived from diffusion-based decompression theory. Undersea Hyperbaric Medicine. 2005, Vol. 32, pp. 429-435.

4. Bühlmann A.A. 1995. Tauchmedizin. Berlin : Springer-Verlag, 1995. ISBN 3-540-58970-8.

5. Huggins K.E. 1992. The dynamics of decompression workbook. Ann Arbor : The University of Michigan, 1992.

6. Imbert J.P., Fructus X. 1991. Short and repetitive decompressions in air diving procedures: the commercial diving experience. [author of the book] Sciences American Academy of Underwater. Proceedings of Repetitive Diving Workshop. Durham, North Carolina: DUKE University Medical Center, 1991, pp. 63-72.

7. Imbert J.P., Hugon J. 2004. In Search of Models Behind Successful Decompressions. [author of the book] SJacquet. Les Tables de Decompression, MT92. Banyuls, Rosselló, Catalunya Nord: Stage de Plongée Scientifique, 2004, pp. 18-32.

8. Kłos R. - 2007. The use of statistical methods in the diving technique. Gdynia : Wydawnictwo Polskiego Towarzystwa Medycyny i Techniki Hiperbarycznej, 2007. ISBN 978-83-924989-2-6.

9. - 2011a. The possibilities of decompression adjustment to CRABE rebreather - assumptions for standard and experimental dives. Gdynia : Polskie Towarzystwo Medycyny i Techniki Hiperbarycznej, 2011a. ISBN 978-83-924989-4-0.

10. - 2011b. Polish Decompression System for CRABE Diving Apparatus. Polish Hyperbaric Research. 2005, Vol. 37, 4, pp. 43-50.

11. - 2012a. Intravascular free gas phase detection. Zeszyty Naukowe Akademii Marynarki Wojennej. 2012a, Vol. 188, ISSN 0860-889X, pp. 8596.

12. - 2012b. The possibilities of oxygen-nitrox exposure adjustment to AMPHORA rebreather-assumptions for standard and experimental dives. Gdynia : Polskie Towarzystwo Medycyny i Techniki Hiperbarycznej, 2012b. ISBN 978-83-924989-8-8.

13. - 2013a. Propose decompression tables for CRABE rebreather and Trimix 23\%O $236 \%$ N 2 41\%He. Gdynia: Akademia Marynarki Wojennej, 2013a. Report no. OTM/TULIPAN III/04-2013.

14. - 2013b. Nitrox and Trimix deep water decompression system for CRABE rebreather - Assumptions for experimental dives. Gdynia: Akademia Marynarki Wojennej, 2013b. OTM/TULIPAN III/06-2013. 
15. - 2014a. Designing experiments for CRABE rebreather - Assumptions for statistical study on the results of experimental dives. Gdynia : Akademia Marynarki Wojennej, 2014a. Report no. OTM/TULIPAN III/07-2014.

16. - 2014b. Nitrox and Trimix deep water decompression system for CRABE rebreather - Completed assumptions for experimental dives Gdynia : Akademia Marynarki Wojennej, 2014b. Report no. OTM/TULIPAN III/09-2014.

17. Shields T.G. Lee W. B 1986. The incidence of decompression sickness arising from commercial offshore air-diving operations in the UK sector of the North Sea during 1982/83. Report to the UK Department of Energy. Sheffield: Health and Safety Executive, 1986. OTO 97812.

18. Williams S. 1975. Engineering principles of underwater breathing apparatus. [author of book] Bennett P.B. Elliott D.H. The physiology and Medicine of diving. London : Bailliere Tidall, 1975, pp. 34-46.

19. Woźniak R. 2014. Security preparation for experimental Trimix dives with the use of CRABE rebreather. Gdynia: Akademia Marynarki Wojennej, 2014. Report no. OTM/TULIPAN III/10-2014.

dr hab. inż. Ryszard Kłos, prof. nadzw.

AMW

Akademia Marynarki Wojennej im.

Bohaterów Westerplatte

Zakład Technologii Prac Podwodnych

81 - 103 Gdynia 3, ul. Śmidowicza 69

Tel.: +58 62627 46, Fax.: +58 6262761

\footnotetext{
${ }^{1}$ Mine Countermeasure,

2 Explosive Ordinance Disposal,

${ }^{3}$ Self-Contained Underwater Breathing Apparatus (SCUBA) with Semi-Closed Circuit (SCR) of trimix (Tx) as a breathing mix in CRABE apparatus,

${ }^{4} \mathrm{O}$ rdinance No. 106 of the Chief of Inspectorate of Armed Forces Support as of 17 November 2010 for the implementation of $C R A B E$ rebreather,
}

${ }^{5}$ helium-nitrogen-oxygen mix

${ }^{6}$ they were presented in previous works. i.e. Kłos R.: Initial analysis of the proposed decompression tables for the CRABE rebreather on the basis of the findings presented in the work Dive conduct and organisation - tab. 7 . Decompression table for a Nitrox containing $30 \% \mathrm{O}_{2}$ : OTM/TULIPAN III/01-2013; Kłos R.: Initial analysis of the proposed decompression tables for the CRABE rebreather on the basis of the findings of the work Dive conduct and organisation - tab. 8. Decompression table for a Trimix containing $23 \% \mathrm{O}_{2} 36 \% \mathrm{~N}_{2} 41 \% \mathrm{He}$ OTM/TULIPAN III/02-2013,

${ }^{7}$ of low DCS hazard

${ }^{8}$ decompression programmes assume breathing with a defined breathing mix - with the implementation of this assumption being enabled only with well-designed open circuit systems,

${ }^{9}$ nitrogen-oxygen mixes,

${ }^{10}$ repeated dives are prohibited,

${ }^{11}$ in semi-closed circuit rebreathers there is a relative decrease in oxygen content in the recirculated breathing mix,

${ }_{12}$ comparative analyses related to the risk of $\mathrm{DCS}$ for $\mathrm{Table} 8 \mathrm{FND}$ ecompressiontableforaTrimixcontain ing $23 \% \mathrm{O}_{2}$

$36 \% \mathrm{~N}_{2} 41 \% \mathrm{He}$ (Aqua Lung France, 2012) and the system proposed by AMW,

${ }^{13}$ unless the supervising doctor decided otherwise, however the minimum observation time was not less than $1.5 h$,

14 in particular the neurological ones,

${ }^{15}$ Diving Medical Officer,

${ }^{16}$ provided that it was possible to generate emergency procedures in the course of theoretical calculations for particular blocks representing various decompression scenarios,

17 to maximum time $100 \mathrm{~min}$; later attempts to apply similar principles in saturation dives were also successful,

${ }^{18}$ more strenuous decompression distributions,

${ }^{19}$ such as age, initial efficiency, fat tissue content, etc.,

${ }^{20}$ calculations are expressed to three decimal places,

${ }^{21}$ values most commonly adopted as limitary $\alpha_{k}$ in statistical reasoning,

22 mainly the ventilation model of the breathing space, the manner of washing off (do you mean washing off or flushing??? washing off suggests what you do after a dive to remove salt from the equipment) the apparatus, permissible workload, etc.,

${ }^{23}$ research results show that probably no gross error had been made, otherwise the threat $\rho$ would be much higher,

${ }^{24}$ such conditions impede the diver's ability to remain position at the station below $3 \mathrm{mH}_{2} \mathrm{O}$ if it is not at least the depth $5-7$ times exceeding the height of waves; in fixed position dives decompression is carried out at the line, which changes its position when the vessel lists,

${ }^{25}$ the Polish Navy utilises decompression tables with decompression stations provided every $3 \mathrm{mH}_{2} \mathrm{O}$,

${ }^{26}$ the Polish Navy applies time reduction in reaching the first decompression station by specifying such time,

${ }^{27}$ mainly the ventilation model of the breathing space, the manner of flushing the apparatus, permissible workload, etc. ,

28 it is possible to accept the tested system, however this could lead to certain impediments in maintaining the required conditions of divers in units, hence it was propose to slightly increase the conservative approach in planning decompression,

${ }^{29}$ repeat dives are prohibited. 